\title{
Microphytobenthos of Arctic Kongsfjorden (Svalbard, Norway): biomass and potential primary production along the shore line
}

\author{
Jana Woelfel • Rhena Schumann • Florian Peine • \\ Anita Flohr · Aleksandra Kruss · Jaroslaw Tegowski • \\ Philippe Blondel $\cdot$ Christian Wiencke $\cdot$ Ulf Karsten
}

Received: 24 August 2009/Revised: 30 March 2010/Accepted: 29 April 2010/Published online: 22 May 2010

(C) The Author(s) 2010. This article is published with open access at Springerlink.com

\begin{abstract}
During summer 2007, Arctic microphytobenthic potential primary production was measured at several stations around the coastline of Kongsfjorden (Svalbard, Norway) at $\leq 5 \mathrm{~m}$ water depth and at two stations at five different water depths $(5,10,15,20,30 \mathrm{~m})$. Oxygen planar optode sensor spots were used ex situ to determine oxygen exchange in the overlying water of intact sediment cores under controlled light (ca. $100 \mu \mathrm{mol}$ photons $\mathrm{m}^{-2} \mathrm{~s}^{-1}$ ) and
\end{abstract}

J. Woelfel $(\bowtie) \cdot$ R. Schumann · U. Karsten

Institute of Biological Sciences, Applied Ecology,

University of Rostock, Albert-Einstein-Strasse 3,

18051 Rostock, Germany

e-mail: jana.woelfel@uni-rostock.de

F. Peine

Institute of Biological Sciences, Marine Biology,

University of Rostock, Albert-Einstein-Strasse 3,

18051 Rostock, Germany

A. Flohr

Center for Marine Tropical Ecology, Fahrenheitstr. 6, 28359 Bremen, Germany

A. Kruss

Institute of Oceanology, Polish Academy of Sciences,

Powstancow Warszawy 55, 81-712 Sopot, Poland

J. Tegowski

Institute of Oceanography, University of Gdańsk,

al. Marszałka Pilsudskiego 46, 81-378 Gdynia, Poland

P. Blondel

Department of Physics, University of Bath,

Claverton Down, Bath BA2 7AY, UK

C. Wiencke

Section Functional Ecology, Department Seaweed Biology,

Alfred-Wegener-Institute for Polar and Marine Research,

Am Handelshafen 12, 27570 Bremerhaven, Germany temperature $\left(2-4^{\circ} \mathrm{C}\right)$ conditions. Patches of microalgae (mainly diatoms) covering sandy sediments at water depths down to $30 \mathrm{~m}$ showed high biomass of up to $317 \mathrm{mg} \mathrm{chl} a \mathrm{~m}^{-2}$. In spite of increasing water depth, no significant trend in "photoautotrophic active biomass" (chl $a$, ratio living/dead cells, cell sizes) and, thus, in primary production was measured at both stations. All sites from $\leq 5$ to $30 \mathrm{~m}$ water depth exhibited variable rates of net production from -19 to $+40 \mathrm{mg} \mathrm{O}_{2} \mathrm{~m}^{-2} \mathrm{~h}^{-1}$ ( -168 to $+360 \mathrm{~m} \mathrm{C} \mathrm{m}^{-2} \mathrm{day}^{-1}$ ) and gross production of about 2-62 $\mathrm{mg} \mathrm{O}_{2} \mathrm{~m}^{-2} \mathrm{~h}^{-1}$ (17-554 $\mathrm{mg} \mathrm{C} \mathrm{m}^{-2}$ day $^{-1}$ ), which is comparable to other polar as well as temperate regions. No relation between photoautotrophic biomass and gross/net production values was found. Microphytobenthos demonstrated significant rates of primary production that is comparable to pelagic production of Kongsfjorden and, hence, emphasised the importance as $\mathrm{C}$ source for the zoobenthos.

Keywords Arctic benthic diatoms - Biomass and chlorophyll $a$. Sediment characteristics .

Respiration and production

\section{Introduction}

Benthic microalgae contribute significantly to the subtidal coastal ecosystem production. Studies from lower latitudes have documented the importance of microphytobenthos for stabilising sediments and supporting shallow water food webs (e.g. reviewed in MacIntyre et al. 1996; Underwood and Kromkamp 1999; Cahoon 1999). Thus, sedimentdwelling microalgae, which are often dominated by diatoms, are the most important primary producers in sandy sediments most common in coastal regions and covering approximately $70 \%$ of the world's shelf regions (Emery 1968). 
Subtidal benthic microalgae on the continental shelves can account for $42 \%$ of the marine benthic primary production (Nelson et al. 1999). According to Cahoon's review (1999) and references therein, the global production of benthic microalgae ranges from 8.9 to $14.4 \mathrm{Gt} \mathrm{C} \mathrm{m}^{-2}$ year $^{-1}$ and represents approximately $20 \%$ of the global ocean production.

While the importance of microalgae in marine benthic habitats has long been recognised and studied extensively over decades in cold- to warm-temperate and even tropical waters (reviewed op. cit.), the role of polar microphytobenthos has received much less attention. The majority of studies on polar benthic microalgae have focussed on freshwater habitats and ice-algae mainly from Antarctica (e.g. Wulff et al. 2009). This is surprising, because unlike other marine systems, the Arctic Ocean is almost completely landlocked. Associated with this extensive land margin, the broad continental shelf of $5 \times 10^{6} \mathrm{~km}^{2}$ comprises about $53 \%$ of the total Arctic Ocean (Pabi et al. 2008). Furthermore, the open water area has increased over the continental shelf at a rate of $0.07 \times 10^{6} \mathrm{~km}^{2} \mathrm{a}^{-1}$ (determined since 1998). Pelagic production of the Arctic Ocean has increased by $5-6 \%$ as a consequence of the resulting increased light availability annually (Arrigo et al. 2008). However, the rising light availability can increase the competition for nutrients. Consequently, benthic primary production may be particularly stimulated in the Arctic Ocean because benthic microalgae can exploit nutrients from sediments released by mineralisation processes directly (Glud et al. 2009).

So far, the number of studies presenting benthic production estimates is very low for the Arctic region. To our knowledge, only 10 studies have been published, of which 6 were written in Russian only (but reviewed in Glud et al. 2009). Assuming 90 days of an open water period, the yearly benthic gross primary production extrapolated to the Arctic coastal region amounts to $1.1-1.6 \times 10^{7} \mathrm{t} \mathrm{C}$ year $^{-1}$ (Glud et al. 2009). This number seems low when compared to the many existing estimates on the pelagic production of the Arctic Ocean ranging from 21 to $42 \times 10^{7}$ t C year $^{-1}$ (e.g. Platt et al. 1982; Subba Rao and Platt 1984; Wassmann and Slagstad 1993; Gosselin et al. 1997). While the annual primary production of Arctic phytoplankton seems generally to be controlled by nitrogen limitation (Pabi et al. 2008), it benefits from a better underwater light climate compared to the microphytobenthos. Thus, nutrient availability often regulates the relative importance of pelagic versus benthic microalgal productivity (Glud et al. 2009).

Although lots of ecological investigations were done at the "Arctic model ecosystem Kongsfjorden", there is a lack of benthic microalgal studies. In the Kongsfjorden review of Hop et al. (2002), microphytobenthos was described as a "largely unknown part of the autotrophic system". Therefore, the aim of the present study was to quantify Arctic benthic microalgal production in Kongsfjorden. It was hypothesised that living benthic diatoms are important primary producers (1) along the coastline of Kongsfjorden at least at sandy areas and (2) also at deeper waters down to $30 \mathrm{~m}$. The depth gradient $(0-30 \mathrm{~m})$ will be reflected in the composition of microalgal assemblages and potential primary productivity. We also determined diatom abundance, which consists of motile cells easily detaching from sediment particles by cell counts and cell size composition. We used a laboratory setup (so called ex situ) for primary production measurements. This setup recorded oxygen changes over undisturbed sediment cores resulting in consumption rates in the dark (respiration) and production at a probably saturating photon flux (potential net production). We applied planar oxygen sensor spots as the detection systems, which are easily accessible and advantageous in this type of experiment. The potential net production will finally be compared to production rates of other phototrophic communities in Polar Regions, such as macrophytobenthos and phytoplankton, to evaluate the role of benthic diatoms for polar matter fluxes and food webs.

\section{Materials and methods}

Study site, sampling and conditions

The study was performed during the polar summer from July to August 2007 in Kongsfjorden $\left(79^{\circ} \mathrm{N}, 12^{\circ} \mathrm{E}\right)$ at the west coast of Svalbard (Fig. 1). Kongsfjorden extends $26 \mathrm{~km}$ from north-west to south-east and its width ranges from 3 to $8 \mathrm{~km}$. The fjord is influenced by the presence of four tidewater glaciers (Fig. 1). Particularly during summer, influxes from the glaciers and terrestrial melt freshwater (enriched with sediment particles) can create steep turbidity, nutrient and salinity gradients along the length of this fjord. Maximum water depth is about $400 \mathrm{~m}$ and the tidal range is about $2 \mathrm{~m}$ (Svendsen et al. 2002). Compared to other locations at this high latitude, air temperature is much higher with an annual mean temperature ranging from $-15^{\circ} \mathrm{C}$ in winter to about $5^{\circ} \mathrm{C}$ in summer. The annual mean water temperature is around $0^{\circ} \mathrm{C}$. The inner part of Kongsfjorden usually becomes ice-covered around December/January. However, the area becomes entirely ice-free during spring and complete ice cover is an exceptional event (Svendsen et al. 2002).

In this study, surface water $(\leq 1 \mathrm{~m})$ temperature in July 2007 varied slightly between 5 and $7^{\circ} \mathrm{C}$ and salinity ranged from 28 to 33 (data not shown). Temperature and salinity were measured with a WTW Salinometer Multiline P4 (WTW GmbH, Weilheim, Germany) as conductivity using the Practical Salinity Scale. Decreasing in water 


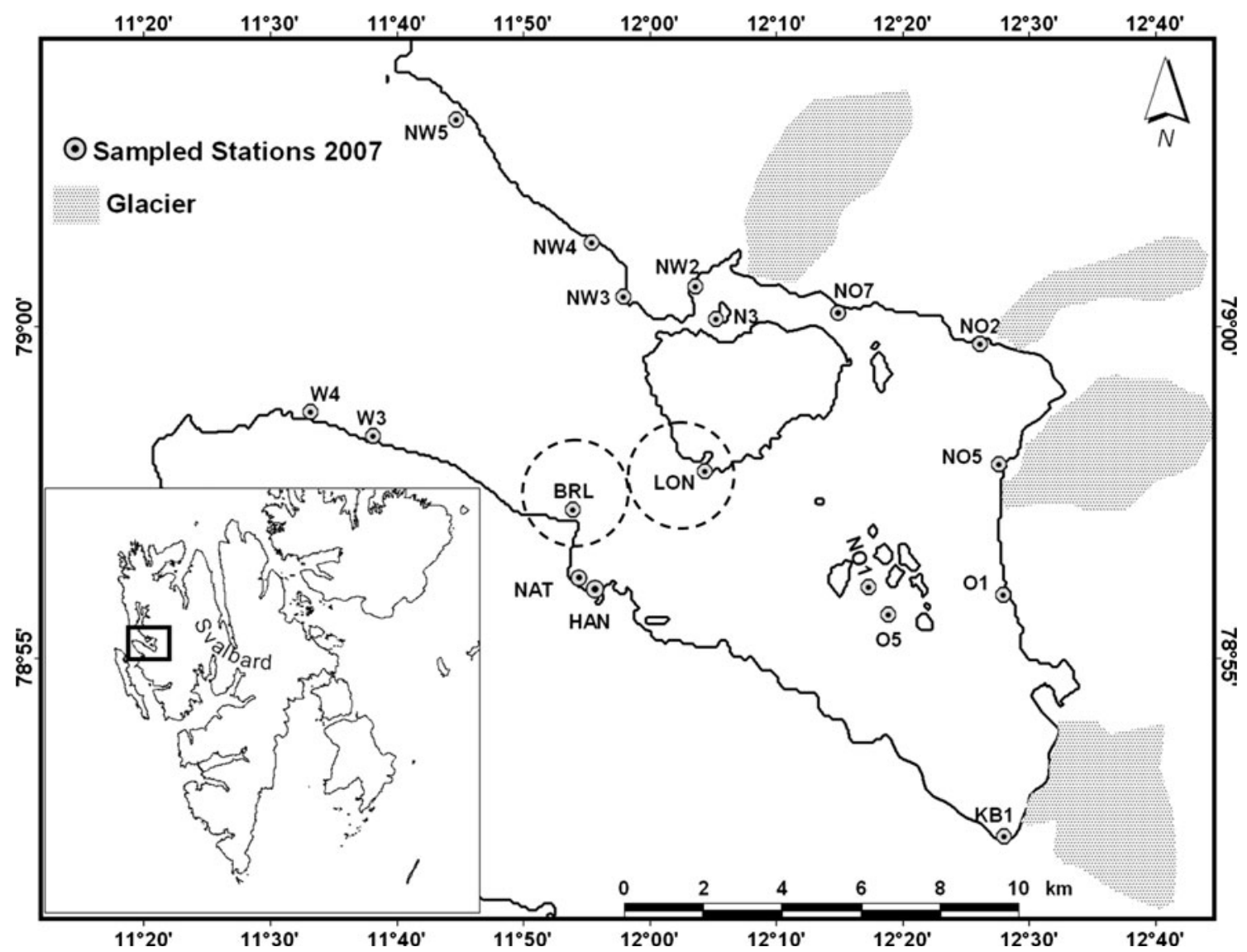

Fig. 1 Location of the sampling stations in Kongsfjorden in 2007. Kongsfjorden on Svalbard (Spitsbergen) is depicted in the map inlet. The four adjacent glaciers are shown as grey areas. The two intensively investigated stations: Brandal (BRL) and London (LON) are marked

transparency was observed in early June. In July, small changes in the vertical attenuation coefficients and PAR data (0.2-0.3; Table 1) indicate that irradiance reduction in the water was marginal. Photon fluence rates varied according to weather conditions (May to July 2006; July 2007 cf. Table 1) with maximum and minimum values ranging from 56 to $288 \mu \mathrm{mol} \mathrm{m} \mathrm{m}^{-2} \mathrm{~s}^{-1}$ at $5 \mathrm{~m}$ water depth (Woelfel et al. 2009a). Thus, light availability was rather similar at all sites down to $5 \mathrm{~m}$ water depth throughout the study period, except in the near vicinity of glaciers, where more turbid water was observed but not analysed.

Sediment samples were taken throughout the fjord and from different water depths, to get an overview of the dependence of benthic microalgal primary production on the glacier's influential factors. At 18 stations at a water depth of $5 \mathrm{~m}$ SCUBA divers collected sediment cores directly in Plexiglas ${ }^{\circledR}$ core liners (inner diameter $50 \mathrm{~mm}$, length $250 \mathrm{~mm}$ ). Some of these stations (especially at the outer area of Kongsfjorden, e.g. W3, W4, NW5) were dominated by rocky substrates and thus not easy to sample, at these stations sandy areas (sediment traps) were chosen. All stations were sampled once and a detailed description of geographical locations (longitude, latitude) is given in
Table 1 Underwater PAR intensities $\left[\mu \mathrm{mol} \mathrm{m} \mathrm{m}^{-2} \mathrm{~s}^{-1}\right]$, vertical attenuation coefficients of downward irradiance (Kd) (calculated: $0.5-5 \mathrm{~m}$ ) and secchi depths [m] measured closed to the Ny Ålesund harbour in Kongsfjorden (2007) under different weather conditions, using a spherical quantum meter (Quantum Li-192 SA. LiCor, Lincoln, USA)

\begin{tabular}{llll}
\hline Water depth & \multicolumn{3}{l}{ PAR $\left[\mu \mathrm{mol} \mathrm{m} \mathrm{m}^{-2} \mathrm{~s}^{-1}\right]$} \\
\cline { 2 - 4 } & 10.07. & 20.07. & 27.07. \\
\hline Surface & 800 & 500 & 870 \\
$0.5 \mathrm{~m}$ & $1,000 \pm 70$ & $286 \pm 23$ & $543 \pm 117$ \\
$1 \mathrm{~m}$ & $670 \pm 0$ & $228 \pm 23$ & $478 \pm 133$ \\
$3 \mathrm{~m}$ & $338 \pm 17$ & $122 \pm 4$ & $294 \pm 49$ \\
$5 \mathrm{~m}$ & $215 \pm 10$ & $80 \pm 1$ & $187 \pm 25$ \\
Weather & Sunny & Overcast & Fair to cloudy \\
Local time & $14: 06$ & $13: 04$ & $13: 08$ \\
Kd & 0.34 & 0.28 & 0.24 \\
Secchi depth $[\mathrm{m}]$ & 5.5 & 6 & 6.6 \\
\hline
\end{tabular}

Data are means \pm SD

Woelfel et al. (2009a). In addition, at two stations (Brandal (BRL) and London (LON)) further sediment samples were taken in transect order at water depths of 5, 10, 15, 20 and 
$30 \mathrm{~m}$ (BRL at 26th and 28th July and LON at 3th and 8th August 2007). The sampling site Brandal (BRL) was more exposed in Kongsfjorden and located off the northern shore, London (LON) was located off the southern shore and sheltered due to its location in a small inlet (Fig. 1). Both stations are representative of Kongfjorden's rare sandy areas and were chosen because of their good accessibility for diving as well as for comparison to a former study of Woelfel et al. (2009a).

Due to high patchiness of microphytobenthic biomass, three replicate cores were taken from each sampling location (sampled from within a $1 \mathrm{~m}^{2}$ area). Intact, undisturbed sediment cores with clear overlying water were selected for production measurements. All sediment cores were transported inside their tubes to the laboratory within a couple of hours under undisturbed, cool and dark conditions. The cores were kept in a cooling room at $2^{\circ} \mathrm{C}$ until subsequent determination of production and biomass (chl $a$, organic matter, cell number), which was done within $2 \mathrm{~h}$ after sample transfer from the field to the lab.

\section{Bottom substrata from echo sounding}

Sediment grain sizes at BRL and LON were only determined in 2006 (Woelfel et al. 2009a). However, for comparison in the present study water content was measured as weight loss after drying pre-weighed sediment samples for $24 \mathrm{~h}$ at $105^{\circ} \mathrm{C}$ in an oven.

Since bottom types were only characterised at these two stations, the question about sediments around Kongsfjorden's coastline had to be addressed. A field survey in 2007 included systematic, co-registered, single-beam and multibeam echo sounder measurements (Kruss et al. 2008). The primary tool for this study was a Biosonics DTX-03-030 single-beam echo sounder (SBES) (BioSonics, Seattle, USA). It operates at $420 \mathrm{kHz}$ with a narrow 3-dB beam width of $5.2^{\circ}$. At a range of $0.5-30 \mathrm{~m}$ and with a pulse length of $0.1 \mathrm{~ms}$, it achieves a resolution of $\sim 0.3-0.9 \mathrm{~m}$ (according to depth) $\times 0.08 \mathrm{~m}$. Research transects were taken perpendicular to the coast, closely following the shores' shape. Based on single beam echo envelopes, statistical features of each clipped ping corresponded to morphological and physical properties of benthic habitats (Tegowski et al. 2003). All data were put into a Matlab-based classification system which used probabilistic neural network for analysis (Kruss et al. 2008). The training set was prepared from representative subsets with: rocky bottom, sandy, muddy and with algae. As echo sounder frequency was very high, it was possible to distinguish with good accuracy only bare bottom, bottom with algae and no bottom, the latter corresponding to depths beyond the range of the echo sounder $(30 \mathrm{~m})$.
Biomass analyses

Three replicate cores were horizontally sectioned into 5-mm slices. Each top $5 \mathrm{~mm}$ slice was weighed and gently homogenised with a spatula. It is unlikely that these samples taken mostly from sandy sediments were modified or crashed during this mixing process. Sand dwelling diatoms are more robust than those from muddy sediments which are less exposed to mechanical stress. Afterwards, subsamples were taken and weighed again for photometric pigment and organic content analysis (POC: particulate organic carbon, PON: particulate organic nitrogen) as well as for cell counting, respectively.

For photometrical chlorophyll analyses, subsamples of ca. 2-4 g fresh weight were extracted in the dark at $4-5^{\circ} \mathrm{C}$ in $5 \mathrm{ml} 90 \%$ acetone $(\mathrm{v} / \mathrm{v})$ for $24 \mathrm{~h}$ with occasional vortex mixing. Afterwards, samples were centrifuged for $5 \mathrm{~min}$ at $7,200 \mathrm{~g}$ and $5^{\circ} \mathrm{C}$, supernatants were collected and absorbance was determined. Pellets were 2 times re-extracted by the same procedure to improve the extraction efficiency in $2.5 \mathrm{ml} \mathrm{90 \%} \mathrm{acetone} \mathrm{each} \mathrm{time.} \mathrm{All} \mathrm{chl} a$ values were quantified according to Jeffrey and Humphrey (1975). Due to no correction for pheopigments, these values may be overestimated.

POC and PON contents were determined in dried samples $\left(6 \mathrm{~h}\right.$ at $\left.105^{\circ} \mathrm{C}\right)$. Samples of $100-150 \mathrm{mg}$ dry weight (DW) were combusted in an elementar analyser (Vario EL, Elementar GmbH, Hanau, Germany) according to Verardo et al. (1990) following acidification of the samples in silver cups with $50-100 \mu \mathrm{l} 10 \% \mathrm{HCl}(\mathrm{v} / \mathrm{v})$ to remove inorganic carbonates. The dry and carbonate free samples were repacked air-tight in tin foil and then measured.

Pre-weighed subsamples for cell counts (abundance) analyses were suspended in $20 \mathrm{ml} 0.2-\mu \mathrm{m}$ filtered sea water from Kongsfjorden and preserved with $2 \%$ glutaraldehyde (v/v) (final concentration). For microscopic analysis, sand particles and organic matter were removed by sieving through a mesh size of $200 \mu \mathrm{m}$. Cell counting chambers with a defined volume of ca. $1 \mathrm{ml}$ were filled with 20-90 times further diluted algal samples. Cells deposited for 6-14 h. Counting was performed with an Olympus microscope $\mathrm{CH} 20$ equipped with a $\times 10 / 0.25$ objective.

Photoautotrophic biomass was composed of $>99 \%$ diatoms. Differentiation between dead/living cells indicates processes of deposition or resuspension of benthic diatoms and plankton cells (water flow conditions) as well as the proportion of "real" active cells to dead organisms. Since no epifluorescence microscope was used, the differentiation was imperfect and is considered for further studies. Since no attempt was applied to remove diatom cells that were attached to sediment particles, the results mainly represent the unattached fraction. However, first, diatom cells were grouped into empty (dead) and filled (living) 
valves. Second, for detailed analyses, cells were grouped into four different size categories: $<20,20-60,60-100$ and $>100 \mu \mathrm{m}$. Besides the intact cells, frustules, which were broken but constituted to more than half of the probable original size, were also counted. This remaining amount of smashed frustules in all samples was always $<5 \%$.

Ex situ primary production

Optical $\mathrm{O}_{2}$ indicators have shown many advantages in comparison to conventional oxygen measurement approaches, like Clark-electrodes or the Winkler-method. They exhibit the highest sensitivity at low $\mathrm{O}_{2}$ concentrations and are not affected by hydrogen sulphide (Kühl and Polerecky 2008), which is often present in sediments. Optodes are especially recommended for on-line measurements over a long time with low oxygen change rates, chemically oxygen consumption, because they do not consume oxygen and do not require subsampling (Woelfel et al. 2009b).

Planar oxygen sensor spots (diameter: $5 \mathrm{~mm}$ ) were glued to the inner wall of air-tight Plexiglas ${ }^{\circledR}$ incubation chambers. Changing oxygen concentrations were measured in the overlying water phase above sediment cores with a Fibox 3 (PreSens GmbH, Regensburg, Germany). The fluorescence signal changes were measured by a $5-\mathrm{m}$-long glass fibre and the recorded parameter was the phase $\left(^{\circ}\right)$. The amplitude signal was additionally used to evaluate the signal quality ( $>10,000$, Christian Krause, Presens Co., personal communication). The reproducibility of planar sensor spots is around $\pm 0.5 \%$ at $85 \mu \mathrm{mol}$ oxygen $1^{-1}$ and $\pm 5 \%$ at $2.83 \mu \mathrm{mol} \mathrm{l}^{-1}$ (Presens, cited in Warkentin et al. 2007). Calibrations were performed in 30 min aerated ambient sea water $(100 \%$ saturation) and in seawater saturated with sodium dithionite solution $\left(0 \%\right.$ oxygen) at $2-4^{\circ} \mathrm{C}$. The phase values were converted into oxygen concentrations using the mathematical conversion matrix of the manufacturer PreSens.

For each location, three replicate sediment cores were sampled directly into respective Plexiglas tubes. The tubes were closed air-tight with a "measuring module" at the top and with a rubber plug at the bottom, which was adjustable for height (tubes: maximal $300 \mathrm{~mm}$ height, inner diameter $50 \mathrm{~mm}$, maximal $589 \mathrm{ml}$ ) (Fig. 2). The volume of each chamber (height of sediment core as well as of the water phase) was determined and integrated into the calculations. The "measuring module" was equipped internally with a planar oxygen sensor spot and a $3 \mathrm{~cm}$ magnetic stirring cross (driven by an external rotating magnet at $6-7 \mathrm{rpm}$ ), which guaranteed optimum mixing in the water column. The measuring module was approximately $110-250 \mathrm{~mm}$ away from each sediment surface. Incubation chambers were filled completely with Kongsfjorden water from the respective sampling sites. Oxygen oversaturation was reduced by short nitrogen bubbling. halogen lamp (ca. $100 \mu$ mol photons $\mathrm{m}^{-2} \mathrm{~s}^{-1}$ )
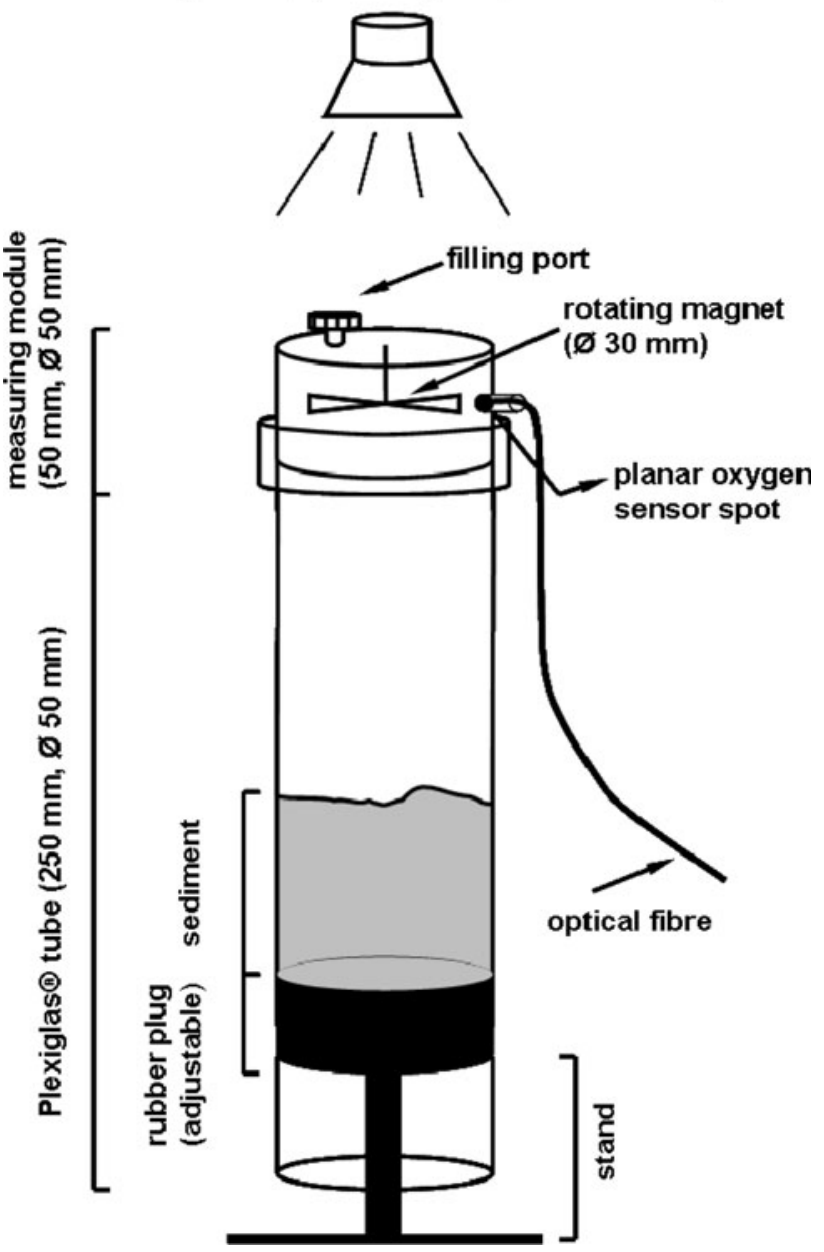

Fig. 2 Schematic illustration of an air-tight incubation Plexiglas ${ }^{\circledR}$ chamber; the sizes are not drawn to the scale

All cores were pre-incubated in the dark at $2^{\circ} \mathrm{C}$, and measurements were run at $2-4^{\circ} \mathrm{C}$ using an ambient seawater flow. Oxygen concentrations in the three respective incubation chambers were read 3-10 times. Each measurement lasted for 5-10 min providing oxygen values every $5 \mathrm{~s}$. Up to $10 \mathrm{~min}$ of initial data were omitted because of changes in phase due to temperature equilibration between sample and spot/chamber. The deviations of oxygen concentrations measured several seconds apart were $0.2 \%$. All cores were first incubated for $2-4 \mathrm{~h}$ in the dark to record oxygen consumption due to community respiration followed by $2-6 \mathrm{~h}$ light treatment for potential production. A halogen lamp (fibre optics of Leica MZ 6 binocular) was used as the light source. Studies of Glud et al. (2002), Leu (2006) and Woelfel et al. (2009a) as well as our values (Table 1) reported an average photon fluence density (PFD) of PAR of about $100 \mu \mathrm{mol}$ photons $\mathrm{m}^{-2} \mathrm{~s}^{-1}$ at $5 \mathrm{~m}$ water depth in Kongsfjorden. Since most samples were taken at approximately $5 \mathrm{~m}$ water depth, our samples were equally 
irradiated with ca. $100 \mu \mathrm{mol}$ photons $\mathrm{m}^{-2} \mathrm{~s}^{-1}$ (core 1: 9598; core 2: 80-92; core 3: 91-98 $\mu \mathrm{mol}$ photons $\mathrm{m}^{-2} \mathrm{~s}^{-1}$ ).

The exchange rates were calculated from the slope of $\mathrm{O}_{2}$ consumption in darkness (respiration) and the $\mathrm{O}_{2}$ change in light (potential net primary production $=$ NPP) in the supernatant water volume. Gross primary production rates (GPP) were calculated as the sum of respiration and NPP rates. These rates were normalised to core (sediment) surface (potential production) or chl $a$ contents (productivity), respectively. All hourly rates were multiplied by 24 (polar day) to obtain daily rates. A photosynthetic quotient $\left(\mathrm{PQ}=\Delta \mathrm{O}_{2} / \Delta \mathrm{C}\right)$ of 1 was used to transform the oxygen values into carbon equivalents (Hargrave et al. 1983).

Data plotting: geographic information system

According to the presentation of data in Peine et al. (2005, 2009), point values from echo sounder measurements were converted into a grid $(1 \mathrm{~m} \times 1 \mathrm{~m})$ covering the study area using Arc-View Spatial Analyst extension software for Arc-View GIS 3.2a. The operation "Neighbourhood Statistics" in this software computes a result grid that represents a mean value on a specified "neighbourhood" around each cell (Wackernagel 1995). In this study, a "circle neighbourhood" of $150 \mathrm{~m}$ was chosen. The values in the result grid are set to the centre cell of each neighbourhood and reflect the function (statistics) applied to the neighbourhood. The echo sounder data were categorised into 5 groups of equal interceptions: water depth $>30 \mathrm{~m}$, mud, sand, rock and algae. The total area of the different substrata was calculated with the internal "Arc-View Spatial Analyst areal calculation" tool and plotted as pie chart within the map (Fig. 3).

Using the same software, increasing values of chl $a$, POC and gross production were plotted as circles of increasing diameter (Fig. 4). The different results were categorised into six groups of equal interceptions.

\section{Results}

\section{Sediment properties}

At Kongsfjorden, finer sediments (fine mud to sand) cover the deeper areas ( $>10 \mathrm{~m}$ water depth). In the inner fjord, the sea floor of depths $<5-10 \mathrm{~m}$ is composed of soft mud most likely deposited from the outflow of the adjacent glaciers (Fig. 3). The classification accuracies of echo sounding division of the bare bottom into sand, rock and mud were only $50 \%$ at this stage, because the survey was designed mostly to investigate spatial distribution of seaweeds and no sediment/bottom samples were taken. Since no bathymetric data exist so far, it is difficult to evaluate the total area down to $30 \mathrm{~m}$ depth of Kongsfjorden's shallow waters.

The total coastline of Kongsfjorden amounts $106.92 \mathrm{~km}$ (coastline without islands: $37.52 \mathrm{~km}$ ) of which we investigated $37.41 \mathrm{~km}$ (coastline without islands: $26.55 \mathrm{~km}$ ) by echo sounding. Thus, $35 \%$ of the total coastline of Kongsfjorden down to $30 \mathrm{~m}$ water depth was characterised.
Fig. 3 Schematic map of the four main substrata down to $30 \mathrm{~m}$ water depth of

Kongsfjorden derived from single- and multibeam echo sounding. Potentially covered areas of extrapolated results are shown as different coloured areas as well as in the pie chart inlet. The four adjacent glaciers are shown as grey areas

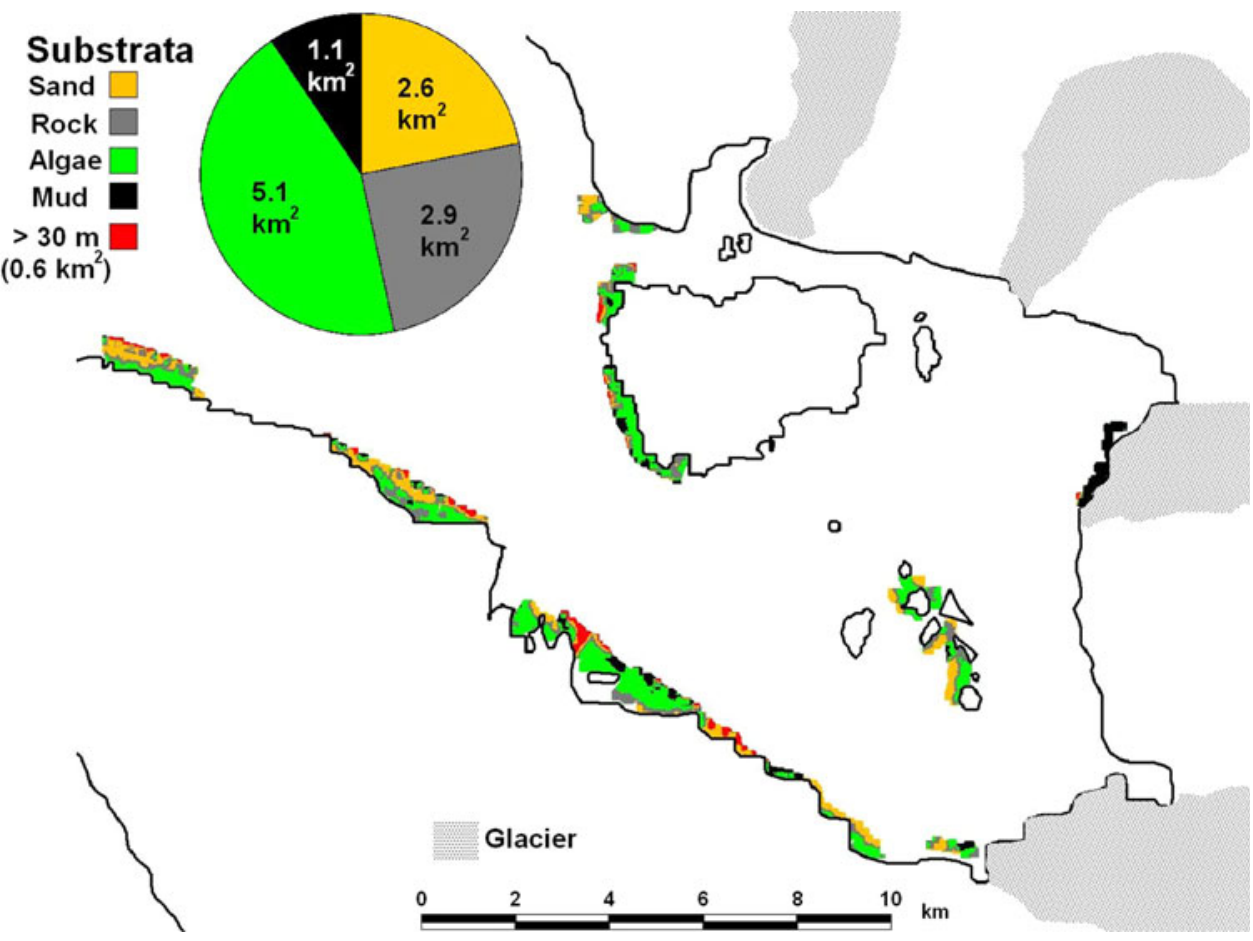




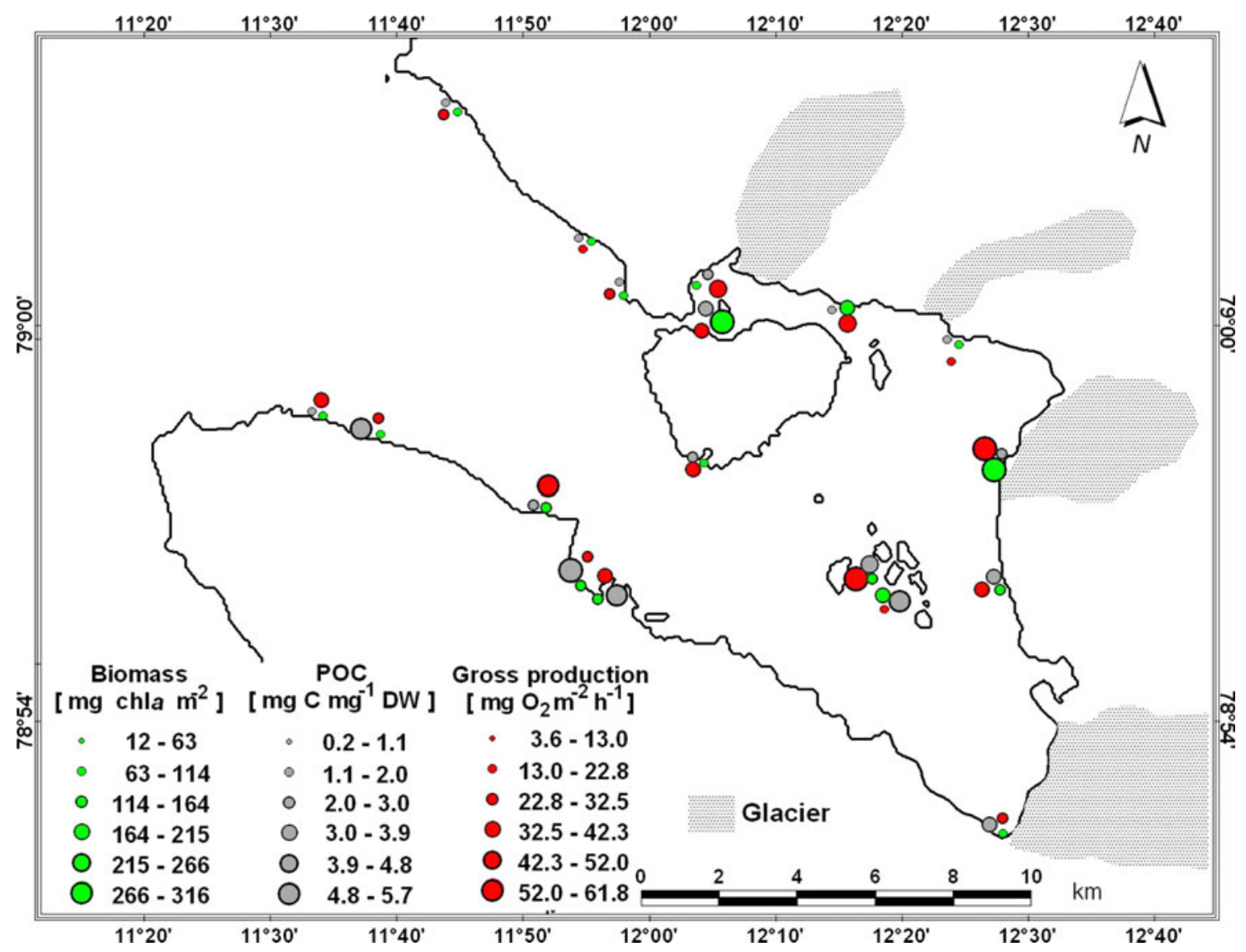

Fig. 4 Photoautotrophic biomass [ $\mathrm{mg} \mathrm{chl} a \mathrm{~m}^{-2}$ ], particulate organic carbon [POC, $\mathrm{mg} \mathrm{C} \mathrm{mg}^{-1} \mathrm{DW}$ ] and rates of gross production $\left[\mathrm{mg} \mathrm{O}_{2} \mathrm{~m}^{-2} \mathrm{~h}^{-1}\right]$ at coastline of Kongsfjorden. All data are mean values of three replicates

Consequently in total, $3.7 \mathrm{~km}^{2}(32 \%)$ of our investigated area was covered with sandy and muddy sediments, which were inhabited by sediment dwelling microalgae. However, the dominant bottom types are rock and macroalgae, which were not investigated for epiphytic and epilithic diatom assemblages.

The water content data of BRL and LON sediments were in the same range as reported in Woelfel et al. 2009a (data not shown). Consequently, there were no changes in sediment grain size at both stations from 2006 to 2007 . The sediment became more fine-grained at both stations with increasing water depths. The predominant sediment type of BRL was middle-grained, well sorted sand (modal particle size of $0.2-0.3 \mathrm{~mm}$ ). At station LON coarser, middlegrained sediments were also determined $(0.44 \mathrm{~mm})$ at water depths of 10 and $15 \mathrm{~m}$ and the grain size decreased to $0.15 \mathrm{~mm}$ at a water depth of $30 \mathrm{~m}$.

\section{Biomass variability}

The microphytobenthic chl $a$ concentrations of all stations in Kongsfjorden indicated a large spatial scale heterogeneity with values ranging from 13 to $317 \mathrm{mg}$ chl $a \mathrm{~m}^{-2}$. A conspicuous geographical trend of biomass in relation to sediment characteristics, turbidity and salinity gradients along the length of this fjord could not be detected (Fig. 4). However, biomass values were lower at both western ends of the coast (stations W4, W3 and NW3-NW5), also called "exterior" area of the fjord, than in the inner fjord. Highest biomass values of $>140 \mathrm{mg}$ chl $a \mathrm{~m}^{-2}$ were measured at stations $\mathrm{O} 5, \mathrm{NO} 5$ and $\mathrm{N} 3$ in front of the glaciers, respectively.

Significant differences in biomass values were not determined at stations LON and BRL, where many samples were taken and compared (Fig. 5). In transects from the shore to $30 \mathrm{~m}$ water depth, chl $a$ concentrations were rather similar and, thus, did not decrease with water depth at LON. At BRL, lowest biomass values of $44 \mathrm{mg} \mathrm{chl} a \mathrm{~m}^{-2}$ were determined at $10 \mathrm{~m}$, while at $30 \mathrm{~m}$ significantly highest values of $129 \mathrm{mg} \mathrm{chl} a \mathrm{~m}^{-2}$ were measured (Fig. 5).

This chl $a$ pattern was well reflected in the unattached diatom cell numbers (Fig. 6). At LON lowest cell numbers were counted in $15 \mathrm{~m}$ water depth with $21.5 \times 10^{3}$ living cells $\mathrm{cm}^{-3}$ and $90-120 \%$ of all counted valves were empty 
Fig. 5 Gradient of phototrophic biomass [chl $a \mathrm{mg} \mathrm{m}^{-2}$ ] in different water depths $[\mathrm{m}]$ at stations Brandal and London; data are mean values with standard deviation $(n=3)$ as error bars. Different letters indicate significantly different means (Tukey's test, $P<0.05$ ). $P$ values in figure indicate results of 1-way ANOVA testing for significant differences among all means (LON: $F_{4,10}=3.32$; BRL:

$F_{4,10}=5.02$ )

Fig. 6 Total cell numbers of living diatom cells and empty valves $10^{3} \mathrm{~cm}^{-3}$ (unattached motile fraction) in relation to water depths $[\mathrm{m}]$ at stations Brandal (a) and London (b); SD of counting: $14 \%$

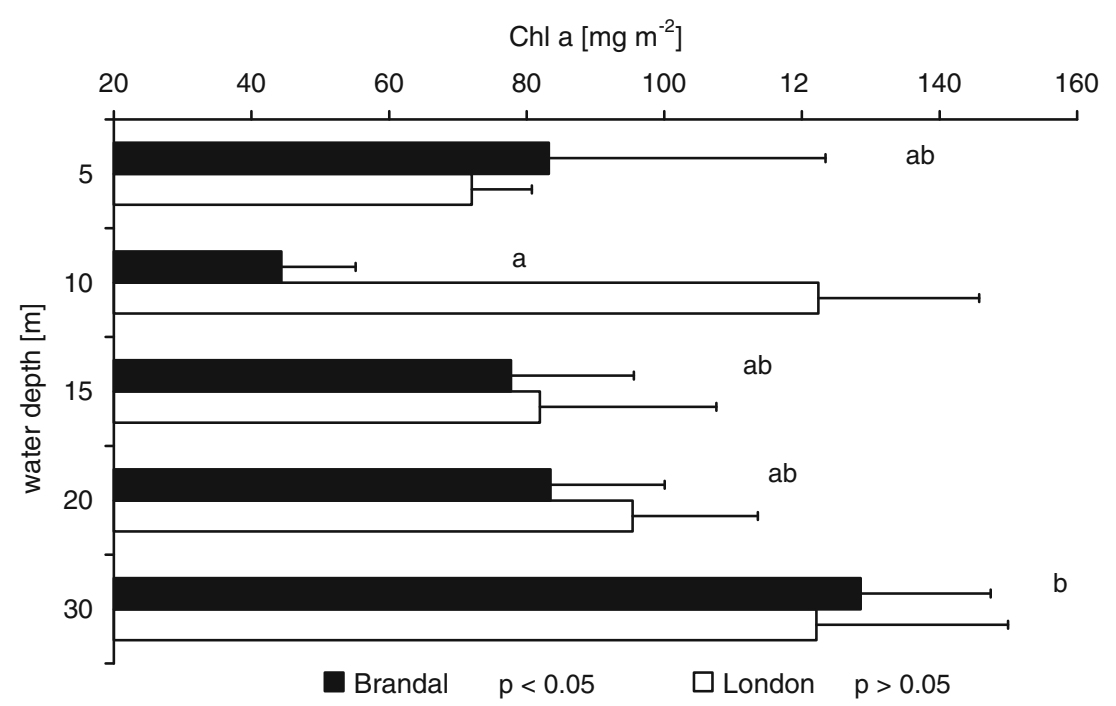

a cell number $10^{3} \mathrm{~cm}^{-3}$
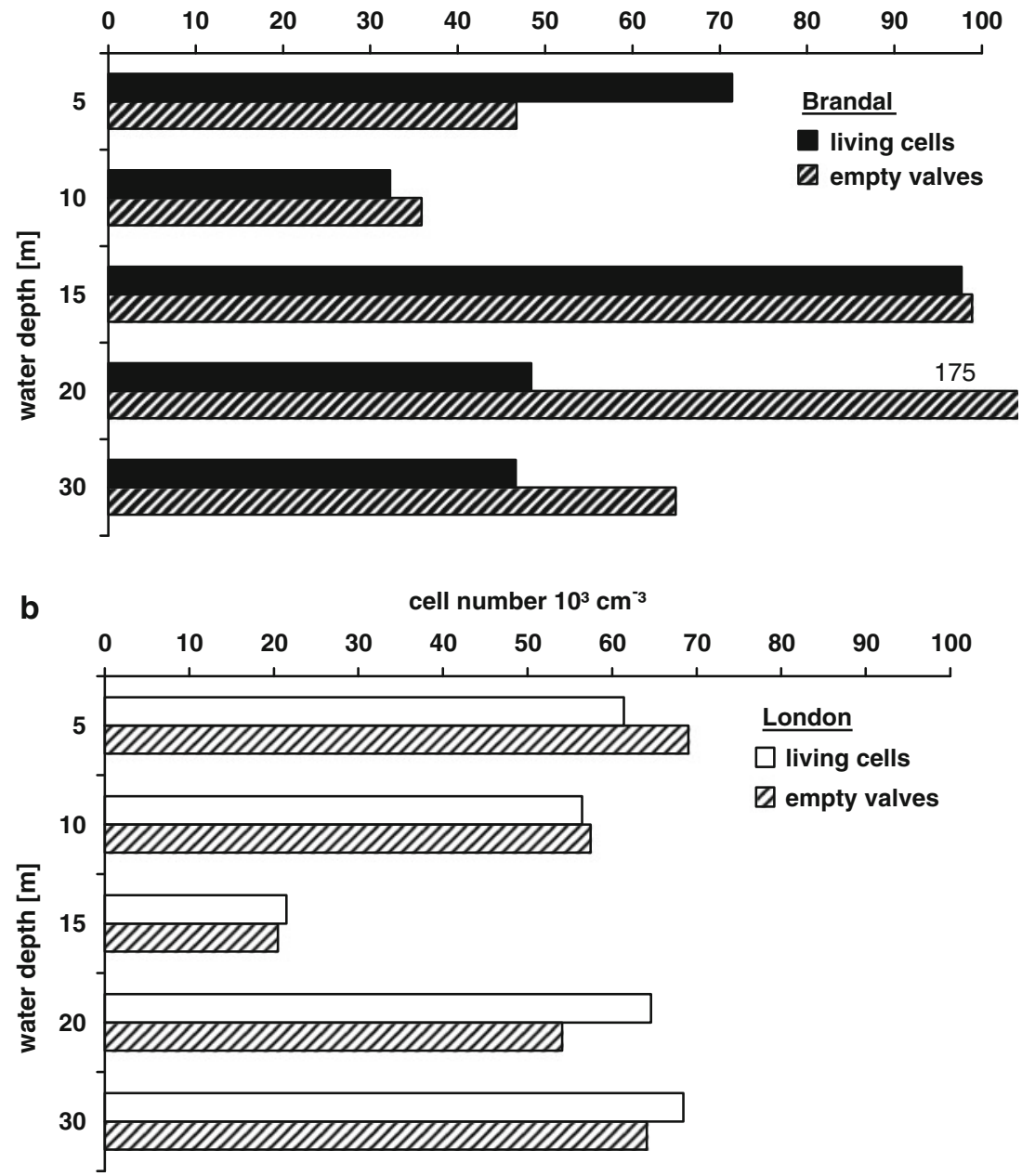

compared to living cells. In contrast at BRL, the fraction of empty valves increased with water depth and highest value of living cells was determined at $15 \mathrm{~m}$ with $98 \times 10^{3} \mathrm{~cm}^{-3}$ (Fig. 6). A conspicuously high number of
$175 \times 10^{3}$ empty valves $\mathrm{cm}^{-3}$ was counted at $20 \mathrm{~m}$. The fraction of living centric diatoms (planktonic or benthic ones, e.g. Paralia sulcata (Ehrenberg) Cleve) in relation to total pennate cell number was moderate with $1-13 \%$. 
Higher percentages of centric diatoms were counted with 26,19 and $21 \%$ (data not shown) only in the deeper waters of BRL at 15, 20, and $30 \mathrm{~m}$, respectively.

Total (living and dead) pennate diatom cell sizes in relation to water depth indicated only slightly differences between BRL and LON (Fig. 7). Both stations were characterised by the dominance of $20-50 \mu \mathrm{m}$ cell size fraction at almost all water depths as well as higher numbers of larger diatom cells in deeper waters. At LON, the $>100 \mu \mathrm{m}$ cell size fraction in $5 \mathrm{~m}$ was lower with $10 \times$ $10^{3}$ cells $\mathrm{cm}^{-3}$ as in $20 \mathrm{~m}$ and $30 \mathrm{~m}$ with $15 \times 10^{3}$ and $33 \times 10^{3}$ cells $\mathrm{cm}^{-3}$, respectively. The cell size fraction of 20-50 $\mu \mathrm{m}$ was more abundant than other sizes and highest at $20 \mathrm{~m}$ with $105 \times 10^{3}$ cells $\mathrm{cm}^{-3}$ at BRL.

High $\mathrm{C}: \mathrm{N}$ and $\mathrm{C}: \mathrm{chl} a$ ratios were associated with high particulate organic carbon (POC) content especially at LON with 2-4 $\mathrm{mg} \mathrm{C} \mathrm{g} \mathrm{DW}^{-1}$ followed by BRL with 1-2.5 mg C g DW ${ }^{-1}$ (Table 2). A high POC content (a sum of detritus, autotrophic as well as heterotrophic organisms) but chl $a$ poor material (reflected in C:chl $a$ ratios of 540$\left.1,040 \mu \mathrm{g} \mathrm{C}(\mu \mathrm{g} \mathrm{chl} a)^{-1}\right)$ was found at LON. In comparison to BRL, onefold to twofold higher $\mathrm{C}: \mathrm{N}$ rates as well as onefold to threefold higher $\mathrm{C}$ : chl $a$ ratios were determined at LON. It is likely that this high amount of organic carbon and chl $a$ poor material tends to result in high oxygen consumption (due to high bacterial respiration/degradation) of this organic matter associated with low net primary production rates.

Primary production

Respiration rates ranged from -2 to $-46 \mathrm{mg} \mathrm{O}_{2} \mathrm{~m}^{-2} \mathrm{~h}^{-1}$ at all stations along the coastline at $\leq 5 \mathrm{~m}$ water depth (Fig. 8). At seven stations (KB1, NO1, NO5, NO7, N3, NW3, NW5), the potential net primary production (NPP) was higher from 6 to $40 \mathrm{mg} \mathrm{O}_{2} \mathrm{~m}^{-2} \mathrm{~h}^{-1}$ than respiration from -2 to $-27 \mathrm{mg} \mathrm{O}_{2}$ $\mathrm{m}^{-2} \mathrm{~h}^{-1}$, indicating the high production activity of benthic microalgae. Three of these stations are located in front of the glaciers (KB1, NO1, NO5) and four stations (NO7, N3, NW3, NW5) at the southern coast. Gross primary production (GPP) rates were strongly influenced by high respiration and showed large spatial scale heterogeneity without any trend in relation to the location at the coastline (Fig. 4). Highest GPP rates from 49
Fig. 7 Cell numbers

$\left[10^{3} \mathrm{~cm}^{-3}\right]$ of different pennate diatom cell sizes (unattached motile fraction) in relation to water depths [m] at stations Brandal (a) and London (b); SD of counting $<20 \mu \mathrm{m} 6 \%$;

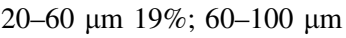
$14 \%$; $>100 \mu \mathrm{m} 62 \%$
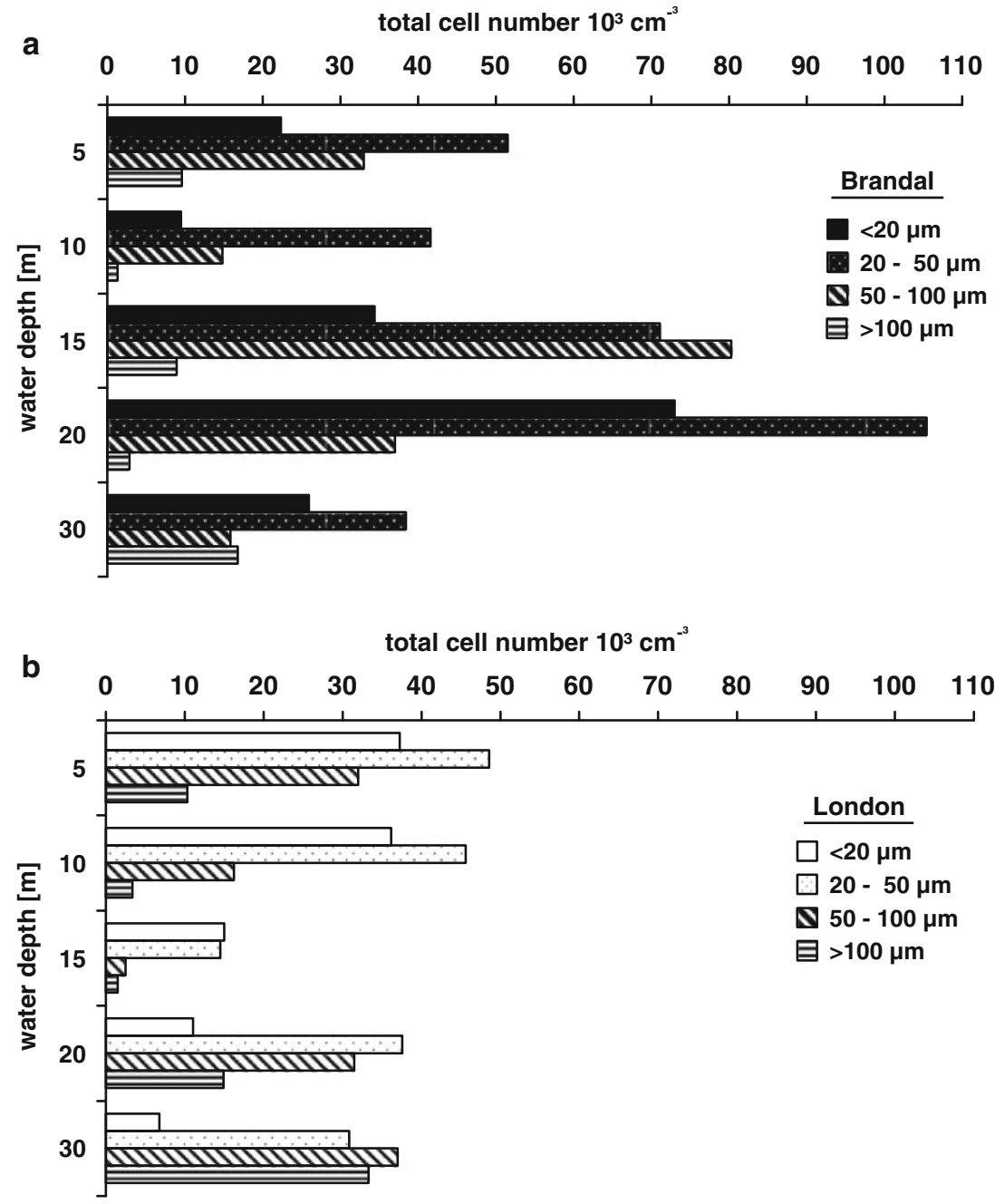
Table 2 Particulate organic carbon $\left[\mathrm{mg} \mathrm{C} \mathrm{g} \mathrm{DW}^{-1}\right], \mathrm{C}: \mathrm{N}$ ratio of organic content and $\mathrm{C}: \mathrm{chl} a$ ratio of biomass in sediments determined in different water depths [m] at two sampling stations Brandal (BRL) and London (LON) in Kongsfjorden (at 28th July and 6th August 2007, respectively) $(n=3-4)$

\begin{tabular}{|c|c|c|c|c|c|c|}
\hline \multirow[t]{2}{*}{$\begin{array}{l}\text { Water } \\
\text { depth }[\mathrm{m}]\end{array}$} & \multicolumn{2}{|c|}{$\begin{array}{l}\text { Particulate organic carbon } \\
{\left[\mathrm{mg} \mathrm{C} \mathrm{g} \mathrm{DW}^{-1}\right]}\end{array}$} & \multicolumn{2}{|c|}{$\begin{array}{l}\mathrm{C}: \mathrm{N} \text { ratio of } \\
\text { organic content }\end{array}$} & \multicolumn{2}{|c|}{$\begin{array}{l}\text { C: chl } a \text { ratio of biomass } \\
{\left[\mathrm{Mg} \mathrm{C} \mathrm{DW}(\mathrm{Mg} \text { chl } a \mathrm{FW})^{-1}\right]}\end{array}$} \\
\hline & BRL & LON & BRL & $\mathrm{LON}$ & BRL & LON \\
\hline 5 & 1.54 & 1.83 & 26.82 & 54.77 & 388.78 & 543.23 \\
\hline 10 & 1.14 & 4.13 & 41.79 & 59.03 & 587.43 & 620.03 \\
\hline 15 & 1.33 & 3.69 & 33.53 & 78.15 & 379.08 & 1039.28 \\
\hline 20 & 1.81 & 3.49 & 28.35 & 32.76 & 407.65 & 777.15 \\
\hline 30 & 2.50 & 4.04 & 31.81 & 58.17 & 387.94 & 612.66 \\
\hline
\end{tabular}

Fig. 8 Rates of ex situ respiration and net production $\left[\mathrm{mg} \mathrm{O}_{2} \mathrm{~m}^{-2} \mathrm{~h}^{-1}\right]$ at various stations from the coastline in Kongsfjorden at ca. $5 \mathrm{~m}$ water depth in July/August 2007. The geographical aspects of the stations, west to east and east to west, in the fjord are given as arrows; data are mean $+\mathrm{SD}$ $(n=3-9)$

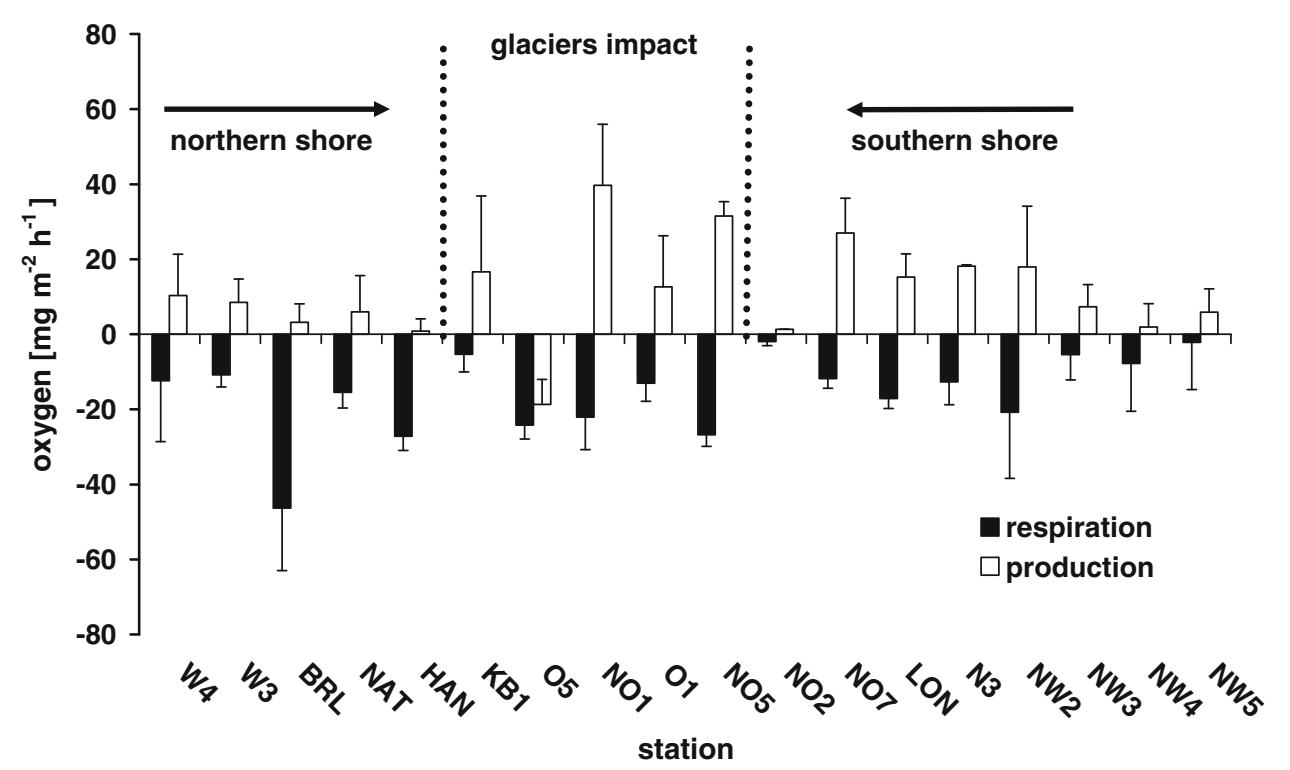

to $62 \mathrm{mg} \mathrm{O}_{2} \mathrm{~m}^{-2} \mathrm{~h}^{-1}$ were measured at stations $\mathrm{KB} 4$, BRL, NO5 and NO1.

Significant differences of productivity between shallow and deeper water were found at LON and BRL (Fig. 9). At 5 and $10 \mathrm{~m}$ water depth (shallow waters), respiration values were 1.5 and 15 fold higher at BRL than at LON. Highest NPP rates from 300 to $243 \mathrm{mg} \mathrm{O} 2 \mathrm{~g}$ chl $a \mathrm{~h}^{-1}$ were determined in the deeper waters $(15-30 \mathrm{~m})$ at BRL. In contrast, highest rates of 221 and $250 \mathrm{mg} \mathrm{O}_{2} \mathrm{~g} \mathrm{chl} a \mathrm{~h}^{-1}$ were measured at 5-10 m water depth at LON. Since NPP and respiration rates were different at LON and BRL, only minor differences between the cumulative GPP rates were calculated. Additionally, the station BRL showed higher productivity than LON.

\section{Discussion}

Primary production set-up

Benthic incubation chambers equipped with oxygen sensor spots open many possibilities to estimate benthic production rates, for example, under different radiation levels (PI-curves) or temperatures. This set-up allows the determination of respiration and net production from sediment samples with a defined area without subsampling or destructing. Replicate cores can be easily incubated and analysed in parallel. However, there are also some methodological limitations. The measuring time is relatively high (4-10 h per station) due to temperature equilibration between sample and spot/chamber. Furthermore, although core or chamber incubations well integrate total activity of the whole sediment dwelling community they provide only a limited insight into their vertical distribution and activity. For vertical measurements, oxygen microelectrode profiling allows a very detailed characterisation of production and consumption at a given depth point. However, the extrapolation of such time-consuming results to larger sediment areas $\left(\mathrm{mm}^{2}\right.$ to $\mathrm{m}^{2}$ scale) is not always simple due to high biomass patchiness. Our benthic incubation chamber set-up integrates the patchiness of organisms corresponding to the covered sediment area of $19.6 \mathrm{~cm}^{2}$. Furthermore, the respective biomass parameters are 
Fig. 9 Rates of ex situ respiration and net production [mg $\mathrm{O}_{2} \mathrm{~g}$ chl $\left.a \mathrm{~h}^{-1}\right]$ at the two stations Brandal (a) and London (b) in relation to different water depths [m]; data are mean values with standard deviation $(n=3)$ as error bars. Different letters indicate significantly different means (Tukey's test, $P<0.05) . P$ values in figure indicate results of one-way ANOVA testing for significant differences among all means $\left(\mathrm{LON}_{\text {prod }}: F_{4,10}=5.32\right.$; $\mathrm{LON}_{\text {resp }}: F_{4,10}=12.49$; BRL ${ }_{\text {prod }}: F_{4,10}=3.26$, BRL $_{\text {resp }}$ : $F_{4,10}=7.68$ )

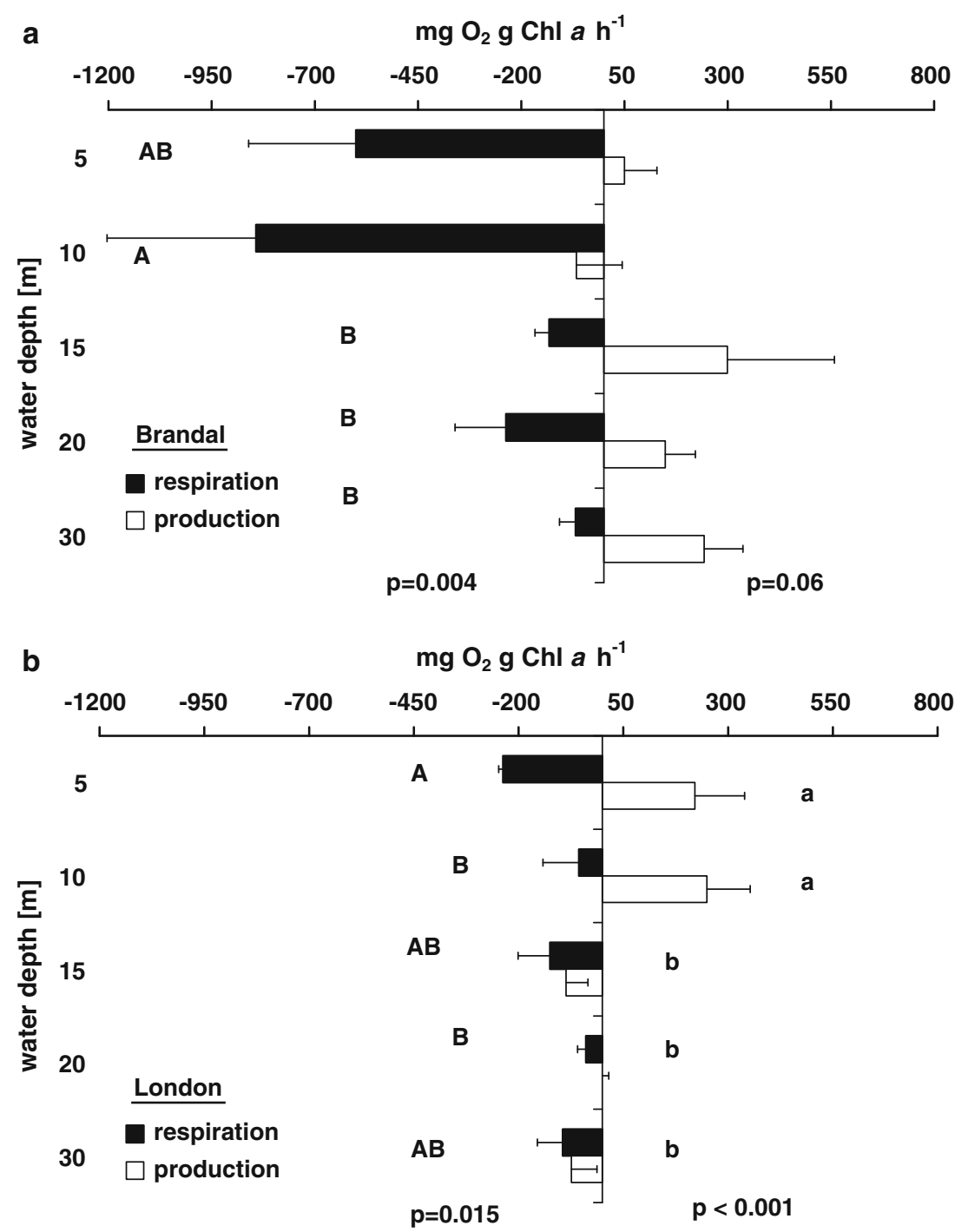

available (in contrast to micro-profile approaches), i.e. chl $a$ per sediment area, volume or mass, from which microphytobenthos productivity can be easily calculated. In conclusion, the combination of microsensors (either optical or Clark-electrodes) and benthic chambers is recommended for an overall characterisation of areal (horizontal/vertical) primary production of microphytobenthos.

The calculation of primary production rates especially the differentiation of gross or net production is difficult. A common procedure to measure gross primary production (GPP) is to add oxygen exchange rates measured in darkness to those determined during light incubations (Glud et al. 2009) as we did in the present study. However, heterotrophic activity in benthic communities is markedly stimulated by light due to a rapid turnover of freshly produced organic material such as exudates (Kühl et al. 1996; Fenchel and Glud 2000). Furthermore, respiration rates of phototrophs are different in darkness and during light exposure (Falkowski and Raven 2007). Additionally, the infauna of shallow waters frequently exhibits a daily variation in their activity level and feeding mode that affects the $\mathrm{O}_{2}$ consumption rate (Wenzhöfer and Glud 2004). Since macroalgal fragments still carry living, active algal cells such as epiphytes, they may contribute to the measured photosynthetic activity and, hence, might result in an overestimation of net primary production (NPP) rates.

Compared to temperate waters (e.g. Woelfel et al. 2007), similar chl $a$ values ranging from 13 to $317 \mathrm{mg}$ chl $a \mathrm{~m}^{-2}$ were determined under the much lower Arctic water temperatures (cf. Table 6 in Woelfel et al. 2009a). High ratios of C:chl $a(380-1,039)$ as well as of C:N (27-78) (Table 2) indicated a carbon-rich organic matter, which was relatively poor in chl $a$ and nitrogen. It is possible that detritus from heterotrophic organisms or macroalgal fragments were extracted from our sediment samples which, of course, would contribute to the data presented. In many sediments only a small portion of POC represents indeed microalgae as up to $10 \%$ of the measured POC was 
Table 3 The existing gross primary production estimates of benthic microalgae for polar regions as determined by in situ incubations as well as some examples from other regions

\begin{tabular}{|c|c|c|c|c|c|c|}
\hline Location & $\begin{array}{l}\text { Water } \\
\text { depth }[\mathrm{m}]\end{array}$ & $\begin{array}{l}\text { GPP range } \\
{\left[\mathrm{mg} \mathrm{C} \mathrm{m}^{-2} \mathrm{~h}^{-1}\right]}\end{array}$ & $\begin{array}{l}\text { Chl } a \\
{\left[\mathrm{mg} \mathrm{m}^{-2}\right]}\end{array}$ & $\begin{array}{l}\text { Measurement } \\
\text { time interval }\end{array}$ & Method & Study \\
\hline \multicolumn{7}{|l|}{ Antarctic } \\
\hline McMurdo Sound & 18 & $51-95$ & $47-533$ & $\begin{array}{l}\text { Sept-Nov 1975; } \\
\text { Mar-Aug } 1977\end{array}$ & ${ }^{14} \mathrm{C}$ & Dayton et al. (1986) \\
\hline Signy Island & 8 & $13-29$ & $10-500$ & $\begin{array}{l}\text { Dec, Jan, Mar } \\
1987 / 1988\end{array}$ & ${ }^{14} \mathrm{C}$ & Gilbert (1991a) \\
\hline \multicolumn{7}{|l|}{ Arctic } \\
\hline Chukchi Sea near Barrow, Alaska & 5 & $0.5-57$ & $35-321$ & Feb-Aug 1972 & ${ }^{14} \mathrm{C}$ & $\begin{array}{l}\text { Matheke and } \\
\text { Horner (1974) }\end{array}$ \\
\hline Narwhal Island, Beaufort Sea & 7 & $<0.01$ & $1-28$ & Apr-Jun 1980 & ${ }^{14} \mathrm{C}$ & $\begin{array}{l}\text { Horner and Schrader } \\
\text { (1982) }\end{array}$ \\
\hline Young Sound, NE Greenland ${ }^{\mathrm{a}}$ & $5-30$ & $0.07-16^{\mathrm{b}}$ & & Jul-Sep 2000 & $\mathrm{O}_{2}$ & Glud et al. (2002) \\
\hline Kongsfjorden, Spitsbergen ${ }^{a}$ & $5-30$ & $1-23^{\mathrm{c}}$ & $13-317$ & Jun-Aug 2007 & $\mathrm{O}_{2}$ & This study \\
\hline \multicolumn{7}{|l|}{ Temperate waters } \\
\hline Westerschelde, SW Netherlands & $\begin{array}{l}\text { Sandy } \\
\text { intertidal flat }\end{array}$ & $15-80$ & $15-32$ & Sept 1995-Oct 1996 & & Barranguet et al. (1998) \\
\hline $\begin{array}{l}\text { German Wadden Sea } \\
\text { (coarse sandy site), Germany }\end{array}$ & $<2$ & $29-51^{\mathrm{c}}$ & $176-194$ & Apr, Aug 2002 & $\mathrm{O}_{2}$ & Billerbeck et al. (2007) \\
\hline $\begin{array}{l}\text { Shallow coastal lagoon } \\
\text { Southern Baltic Sea, Germany }\end{array}$ & 2.5 & $6-18$ & $135-209$ & $\begin{array}{l}\text { May, Jul, Sep 1996; } \\
\text { Jan, Apr } 1997\end{array}$ & $\mathrm{O}_{2}$ & $\begin{array}{l}\text { Meyercordt and } \\
\text { Meyer-Reil (1999) }\end{array}$ \\
\hline
\end{tabular}

allocated to living microorganisms (K. Sundbäck, personal communication). Nevertheless, the values presented here are mainly within the range of published data (cf. De Jonge 1980) although almost all C:chl $a$ ratios were obtained from phytoplankton assemblages. In conclusion, since $\mathrm{C}: \mathrm{chl} a$ ratios are insufficient to describe changes in benthic microalgal standing stock, diatom cell counts should be used as biomass reference values.

All NPP rates were highly depended on respiration rates. We observed that almost all sediment samples and 30-80\% of each sediment surface was strongly populated by polychaetes and nematodes. Sediments of BRL at $20 \mathrm{~m}$ water depth, for example, showed abundances of 12,21016,130 animals $\mathrm{cm}^{-2}$ dominated by nematodes and copepods (Veit-Köhler et al. 2008). These dense communities of meiobenthic organisms as well as protozoa and bacteria probably strongly contributed to the measured high respiration rates. Thus, determination of NPP and respiration enables a more detailed discussion of sediment ecology.

Oxygen exchange was transformed into a $\mathrm{CO}_{2}$ fixation rate assuming a photosynthetic quotient (PQ). For integrated benthic communities, most determinations of PQ range between 0.9 and 1.3 depending on light and nutrient availability (Hargrave et al. 1983; Cahoon and Cooke 1992; Ni Longphuirt et al. 2007). Based on 50 incubations of sediment cores, the community PQ of a high Arctic sediment averaged at $1.19 \pm 0.48$ (Glud et al. 2002). However, most published primary production studies do not provide sufficient information in respect to terms and values of carbon- or oxygen-based measurements (e.g. PQ, incubation period, respiration, etc.) to recalculate the reported values as GPP or NPP rates. Consequently, a PQ of 1 was used in this study and, thus, probably underestimates the true carbon NPP and GPP values. Although primary production of benthic microalgae from Polar Regions has mostly been estimated from ${ }^{14} \mathrm{C}$-incubations, our GPP rates down to $30 \mathrm{~m}$ water depth in Kongsfjorden were similar (Table 3). However, the cumulative GPP does not represent the high respiration activity in sediments.

\section{Heterogeneity in productivity}

Only minor changes of chl $a$ concentrations (Fig. 5) as well as of the ratios of living/dead cells (Figs. 4, 5) were determined with increasing transect depth. The GPP did not change likewise indicating that light availability is sufficient for microalgal growth down to $30 \mathrm{~m}$. However, benthic diatoms are capable to quickly optimise their photosynthetic apparatus to the actual irradiance and to thrive well under low-light conditions (Glud et al. 2002; Karsten et al. 2006). Some taxa are motile (epipelic) and migrate depended on light and nutrient conditions. 
Consequently, any expected depth-specific light acclimation of the transect biomass was neglected when exposed to similar radiation conditions in the laboratory.

Diatom cell sizes of $20-50 \mu \mathrm{m}$ were dominating both stations at all water depths. At LON, a slight increase in diatom cell size with increasing water depth was determined (Fig. 7). This might indicate grazer selectivity for certain size classes or growth stimulation of this special group. In addition, large diatoms seem to be particularly well adapted to low-light levels (cf. Gillespie et al. 2000). Generally, diatoms can grow and/or survive under very low irradiances (single photons $\mathrm{m}^{-2} \mathrm{~s}^{-1}$ ) (Wulff et al. 2005; Cahoon 1999). A preference for moderate depths was found along a depth gradient on the Swedish West coast, where higher chl $a$ was found in 14-16 m (Sundbäck and Jönsson 1988). However, this preference could also been related to less physical disturbance such as wave action. A negative correlation between diatom diversity and depth (7-25 m) was found in sediments of the Gullmar fjord (Swedish West coast) (Wulff et al. 2005). Temperature, salinity and light intensities explained only $57 \%$ of diatom taxa variation, and light was not the main environmental factor. Consequently, for further studies, a multivariate qualitative and quantitative analysis of light intensities, hydrodynamic conditions, grazing impacting biomass, species composition and primary production is necessary.

\section{Importance of benthic microalgae in Kongsfjorden}

Primary production rates of benthic microalgae on sandy sediments of the permanently cold Arctic Kongsfjorden were similar to those in temperate waters (Table 3). However, this study represents potential primary production rates since the communities were exposed to an (artificial) radiation of ca. $100 \mu \mathrm{mol} \mathrm{m} \mathrm{m}^{-2} \mathrm{~s}^{-1}$, which most likely reflected the upper limit of polar environmental conditions in Kongsfjorden. Although this radiation level was moderate, benthic microalgal communities rarely exhibit photoinhibition or even photodamage (Glud et al. 2009). Moreover, a downward migration of motile diatoms counteracts efficiently inhibiting light levels at the sediment surface (Kühl et al. 1997). Total diatom cell numbers including attached microalgae are typically in the order of $10^{5}-10^{6}$ (K. Sundbäck, personal communication). In our study, cell number of the unattached fraction was significant with $10^{3}$, which may point to a high migration potential of these microalgae. However, further studies on attached microalgae have to be done.

Relatively high potential GPP rates ranging from 12 to $23 \mathrm{mg} \mathrm{C} \mathrm{m}^{-2} \mathrm{~h}^{-1}$ seem to coincide with smaller grain size and lower wave exposure (water depth $\leq 5 \mathrm{~m}$ ). Thus, at the "exterior" area of the fjord, where the water flow is higher and grain sizes coarser (3-9 $\left.\mathrm{mg} \mathrm{C} \mathrm{m}^{-2} \mathrm{~h}^{-1}\right)$, biomass and production rates were lower than in the inner fjord (Fig. 4). Only $32 \%$ of the area investigated by echo sounding was covered with sandy and muddy sediments, whereas macroalgal biomass covered about $44 \%$ (Kruss et al. 2008). This coverage clearly indicates rocky substrates, which are most common in Kongsfjorden. Although not investigated in the present study, thick mats of microalgae are reported to grow on nearly all surfaces including rocks and seaweeds in shallow waters along Kongsfjorden (Hop et al. 2002). For a more precise calculation of total microphytobenthic production, investigations into epiphytic and epilithic microalgae are urgently needed.

The number of studies quantifying microphytobenthic biomass is much larger than those determining microphytobenthic activity, although chl $a$ was often used as an indicator for production of these microalgae (Cahoon 1999; Glud et al. 2009). It is beyond dispute that biomass values are dependent on the "balance" between accumulation (e.g. growth, deposition, migration) and removal (e.g. grazing, resuspension, senescence) processes as well as on abiotic conditions. In respect to the low water temperatures of the Arctic, the degradation of organic matter could be slower than in temperate regions. Furthermore, the photic zone only extends a few $\mathrm{mm}$ into the sediment, but the chl $a$ concentration is averaged over the uppermost $\mathrm{cm}$ and, therefore, it poorly represents phototrophic production (Kühl 2005). Consequently, chl $a$ concentrations or POC values represent poor proxies for benthic productivity as well as for production values (photoautotrophic or heterotrophic) especially when they are extrapolated to larger areas. Due to the high oxygen consumption by heterotrophic processes in the sediment the three parameters biomass, net production and respiration have to be jointly determined for precise estimation of production as well as productivity.

The ice-free summer of 90-120 days in the Arctic reflects undoubtedly the main period for benthic production (Cahoon 1999). So far, not much is known to what extent polar benthic microalgae are able to cope with prolonged periods of low light or even darkness in winter and beneath sea-ice. Microalgae were present in sediments at Signy Island (Antarctica) all year round and rapidly increased in biomass following the onset of light in following spring (Gilbert 1991b). Benthic microalgae became the most important primary producers after the breakup of the nearshore ice in the Chukchi Sea (Alaska, USA) (Matheke and Horner 1974). In the latter study, primary production of benthic microalgae was 8 times higher than that of ice algae and twice than of phytoplankton. However, benthic productivity was found to be negligible at another Arctic site during spring when ice algae contributed most to total primary production (Horner and Schrader 1982). This indicates that benthic production may only occur at specific 
times during polar summer or that substantial differences occur between sites. Based on an average of 90 days of open water and $24 \mathrm{~h}$ light, a mean summer potential primary production rate of $212 \mathrm{mg} \mathrm{C} \mathrm{m}^{-2}$ day $^{-1}$ was estimated for Kongsfjorden, which equals $19 \mathrm{~g} \mathrm{C} \mathrm{m}^{-2}$ year $^{-1}$ per summer period. Yearly GPP rates of microphytobenthos extrapolated to the Kongsfjorden sandy and muddy areas ( $\mathrm{sum}=3.7 \mathrm{~km}^{2}$ of the investigated area down to $30 \mathrm{~m}$ depth) amounts to $76-1,900 \mathrm{~kg} \mathrm{C}$ year ${ }^{-1}$ on average. However, further work is required to assess diatom behaviour under low-light conditions and seasonal production of benthic microalgae.

At all investigated sites $(5-30 \mathrm{~m})$, benthic microalgal production was with $1-23 \mathrm{mg} \mathrm{C} \mathrm{m}^{-2} \mathrm{~h}^{-1}$ similar to pelagic production values of $3-5 \mathrm{mg} \mathrm{C} \mathrm{m}^{-2} \mathrm{~h}^{-1}$ in Kongsfjorden and of $14-87 \mathrm{mg} \mathrm{C} \mathrm{m}^{-2} \mathrm{~h}^{-1}$ in Hornsund (West Spitsbergen coast) during July 2002 (Piwosz et al. 2009). From these data, the annual pelagic primary production $(5-100 \mathrm{~m})$ can be calculated as $2-14 \mathrm{~g} \mathrm{C} \mathrm{m}^{-2}$ year $^{-1}$ in Kongsfjorden. In comparison to our estimates, the potential of benthic microalgal production was 2 times higher and at least in the same range as the pelagic production values, which supports the important ecological role of microphytobenthos as a food source for the heterotrophs in Kongsfjorden. In summary, the entire Arctic region is still undersampled and further studies on benthic primary production either of macroalgae or microalgae should be encouraged.

Acknowledgments This work has been performed at the Ny- $\AA$ lesund International Arctic environmental Research and Monitoring Facility and under the agreement on scientific cooperation between the Alfred Wegener Institute and the University of Rostock. The authors thank the crew at the AWIPEV-base in Ny Alesund (Rainer Vockenroth, Mareike Peterson, Jonathan Plößl) and especially the German dive team (Peter Leopold, Max Schwanitz, Mark Olischläger) for assistance in the field and collecting the samples. Special thanks to Juliane Buss for determination of POC as well as to Eileen Kubitzke for cell counting. The sediment tube setup for primary production measurements was manufactured by Peter Kumm (Institute of Chemistry, University of Rostock). Thanks to Ruth Müller (AWI) for providing PAR data. Data for bottom depth and substrate type evaluation were possible by financial support of ARCFAC V (project no. 026129-70). We further gratefully acknowledge financial support by the German Research Council (DFG, KA899/12-1/2/3) and the Alfred Wegener Institute for Polar and Marine Research, Germany.

Open Access This article is distributed under the terms of the Creative Commons Attribution Noncommercial License which permits any noncommercial use, distribution, and reproduction in any medium, provided the original author(s) and source are credited.

\section{References}

Arrigo KR, van Dijken G, Pabi S (2008) Impact of a shrinking Arctic ice cover on marine primary production. Geophys Res Lett 35:L19603. doi:10.1029/2008GL035028
Barranguet C, Kromkamp J, Peene J (1998) Factors controlling primary production and photosynthetic characteristics of intertidal microphytobenthos. Mar Ecol Prog Ser 173:117-126

Billerbeck M, Roy H, Bosselmann K, Huettel M (2007) Benthic photosynthesis in submerged Wadden Sea intertidal flats. Estuar Coast Shelf Sci 71:704-716

Cahoon LB (1999) The role of benthic microalgae in neritic ecosystems. Oceanogr Mar Biol Annu Rev 37:47-86

Cahoon LB, Cooke JE (1992) Benthic microalgal production in Onslow Bay, North-Carolina, USA. Mar Ecol Prog Ser 84:185196

Dayton PK, Watson D, Palmisano A, Barry JP, Oliver JS, Rivera D (1986) Distribution patterns of benthic microalgal standing stock at McMurdo Sound, Antarctica. Polar Biol 6:207-213

De Jonge VN (1980) Fluctuations in the organic-carbon to chlorophyll-alpha ratios for estuarine benthic diatom populations. Mar Ecol Prog Ser 2:345-353

Emery KO (1968) Relict sediments on continental shelves of the world. Am Assoc Petroleum Geol Bull 52:445-464

Falkowski PG, Raven JA (2007) Aquatic photosynthesis. Princeton University Press, Princeton

Fenchel T, Glud RN (2000) Benthic primary production and $\mathrm{O}_{2}-\mathrm{CO}_{2}$ dynamics in a shallow-water sediment: spatial and temporal heterogeneity. Ophelia 53:159-171

Gilbert NS (1991a) Primary production by benthic microalgae in nearshore marine-sediments of Signy Island, Antarctica. Polar Biol 11:339-346

Gilbert NS (1991b) Microphytobenthic seasonality in near-shore marine-sediments at Signy Island, South Orkney Islands, Antarctica. Estuar Coast Shelf Sci 33:89-104

Gillespie PA, Maxwell PD, Rhodes LL (2000) Microphytobenthic communities of subtidal locations in New Zealand: taxonomy, biomass, production, and food-web implications. N Z J Mar Freshwat Res 34:41-53

Glud RN, Kuhl M, Wenzhofer F, Rysgaard S (2002) Benthic diatoms of a high Arctic fjord (Young Sound, NE Greenland): importance for ecosystem primary production. Mar Ecol Prog Ser 238:15-29

Glud RN, Woelfel J, Karsten U, Kühl M, Rysgaard S (2009) Benthic microalgal production in the Arctic: applied methods and status of the current database. Bot Mar 52:559-571

Gosselin M, Levasseur M, Wheeler PA, Horner RA, Booth BC (1997) New measurements of phytoplankton and ice algal production in the Arctic Ocean. Deep Sea Res Part II 44:1623-1644

Hargrave BT, Prouse NJ, Phillips GA, Neame PA (1983) Primary production and respiration in the pelagic and benthic communities at two intertidal sites in the upper Bay of Fundy. Can J Fish Aquat Sci 40:43-229

Hop H, Pearson T, Hegseth EN, Kovacs KM, Wiencke C, Kwasniewski S, Eiane K, Mehlum F, Gulliksen B, WlodarskaKowalezuk M, Lydersen C, Weslawski JM, Cochrane S, Gabrielsen GW, Leakey RJG, Lonne OJ, Zajaczkowski M, Falk-Petersen S, Kendall M, Wangberg SA, Bischof K, Voronkov AY, Kovaltchouk NA, Wiktor J, Poltermann M, di Prisco G, Papucci C, Gerland S (2002) The marine ecosystem of Kongsfjorden, Svalbard. Polar Res 21:167-208

Horner R, Schrader GC (1982) Relative contributions of ice algae, phytoplankton, and benthic microalgae to primary production in nearshore regions of the Beaufort Sea. Arctic 35:485-503

Jeffrey SW, Humphrey GF (1975) New spectrophotometric equations for determining chlorophylls A, B, C1 and C2 in higher-plants, algae and natural phytoplankton. Biochem Physiol Pflanz 167:191-194

Karsten U, Schumann R, Rothe S, Jung I, Medlin L (2006) Temperature and light requirements for growth of two diatom species (Bacillariophyceae) isolated from an Arctic macroalgae. Polar Biol 29:476-486 
Kruss A, Blondel Ph, Tęgowski J (2008) Estimation of macrophytes using single-beam and multibeam echosounding for environmental monitoring of Arctic fjords (Kongsfjord, West Svalbard Island). J Acoust Soc Am 123:3213

Kühl M (2005) Optical microsensors for analysis of microbial communities. Meth Enzymol 397:166-199

Kühl M, Polerecky L (2008) Functional and structural imaging of phototrophic microbial communities and symbioses. Aquat Microb Ecol 53:99-118

Kühl M, Glud RN, Ploug H, Ramsing NB (1996) Microenvironmental control of photosynthesis and photosynthesis-coupled respiration in an epilithic cyanobacterial biofilm. J Phycol 32:799-812

Kühl M, Lassen C, Revsbech NP (1997) A simple light meter for measurements of PAR (400-700 nm) with fiber-optic microprobes: application for P vs. I measurements in microbenthic communities. Aquat Microb Ecol 13:197-207

Leu E (2006) Effects of a changing arctic light climate on the nutritional quality of phytoplankton. Dissertation, University of Oslo

MacIntyre HL, Geider RJ, Miller DC (1996) Microphytobenthos: the ecological role of the "secret garden" of unvegetated, shallowwater marine habitats. 1. Distribution, abundance and primary production. Estuaries 19:186-201

Matheke GEM, Horner R (1974) Primary productivity of benthic microalgae in Chukchi Sea Near Barrow, Alaska. J Fish Res Board Can 31:1779-1786

Meyercordt J, Meyer-Reil LA (1999) Primary production of benthic microalgae in two shallow coastal lagoons of different trophic status in the southern Baltic Sea. Mar Ecol Prog Ser 178:179191

Nelson J, Eckmann J, Robertson C, Marinelli R, Jahnke R (1999) Benthic microalgal biomass and irradiance at the sea floor on the continental shelf of the South Atlantic Bight: spatial and temporal variability and storm effects. Cont Shelf Res 19:477505

Ni Longphuirt SN, Clavier J, Grall J, Chauvaud L, Le Loch F, Le Berre I, Flye-Sainte-Marie J, Richard J, Leynaert A (2007) Primary production and spatial distribution of subtidal microphytobenthos in a temperate coastal system, the Bay of Brest, France. Estuar Coast Shelf Sci 74:367-380

Pabi S, van Dijken GL, Arrigo KR (2008) Primary production in the Arctic Ocean, 1998-2006. J Geophys Res Oceans 113:C08005. doi:10.29/2007JC004578

Peine F, Bobertz B, Graf G (2005) Influence of the blue mussel Mytilus edulis (Linnaeus) on the bottom roughness length $\left(z_{0}\right)$ in the south-western Baltic Sea. Baltica 18:13-22

Peine F, Friedrichs M, Graf G (2009) Potential influence of tubicolous worms on the bottom roughness length $z(0)$ in the south-western Baltic Sea. J Exp Mar Biol Ecol 374:1-11

Piwosz K, Walkusz W, Hapter R, Wieczorek P, Hop H, Wiktor J (2009) Comparison of productivity and phytoplankton in a warm (Kongsfjorden) and a cold (Hornsund) Spitsbergen fjord in midsummer 2002. Polar Biol 32:549-559

Platt T, Harrison WG, Irwin B, Horne EP, Gallegos CL (1982) Photosynthesis and photoadaptation of marine phytoplankton in the Arctic. Deep Sea Res 29:1159-1170
Subba Rao DV, Platt T (1984) Primary production of arctic waters. Polar Biol 3:191-201

Sundbäck K, Jönsson B (1988) Microphytobenthic productivity and biomass in sublittoral sediments of a stratified bay, Southeastern Kattegat. J Exp Mar Biol Ecol 122:63-81

Svendsen H, Beszczynska-Moller A, Hagen JO, Lefauconnier B, Tverberg V, Gerland S, Orbaek JB, Bischof K, Papucci C, Zajaczkowski M, Azzolini R, Bruland O, Wiencke C, Winther JG, Dallmann W (2002) The physical environment of Kongsfjorden-Krossfjorden, an Arctic fjord system in Svalbard. Polar Res 21:133-166

Tegowski J, Gorska N, Klusek Z (2003) Statistical analysis of acoustic echoes from underwater meadows in the eutrophick Puck Bay (Southern Baltic Sea). Aquat Living Resour 16:215221

Underwood GJC, Kromkamp J (1999) Primary production by phytoplankton and microphytobenthos in estuaries. Adv Ecol Res 29:93-153

Veit-Köhler G, Laudien J, Knott J, Velez J, Sahade R (2008) Meiobenthic colonisation of soft sediments in arctic glacial Kongsfjorden (Svalbard). J Exp Mar Biol Ecol 363:58-65

Verardo DJ, Froelich PN, Mcintyre A (1990) Determination of organic-carbon and nitrogen in marine-sediments using the Carlo-Erba-Na-1500 Analyzer. Deep Sea Res Part A Oceanogr Res Pap 37:157-165

Wackernagel H (1995) Multivariate geostatistics: an introduction with applications. Springer, Berlin

Warkentin M, Freese HM, Karsten U, Schumann R (2007) New and fast method to quantify plankton community respiration by optical oxygen sensor spots. Appl Environ Microbiol 73:67226729

Wassmann P, Slagstad D (1993) Seasonal and annual dynamics of particulate carbon flux in the Barents Sea: a model approach. Polar Biol 13:363-372

Wenzhöfer F, Glud RN (2004) Small-scale spatial and temporal variability in benthic $\mathrm{O}_{2}$ dynamics of coastal sediments: impact of fauna activity. Limnol Oceanogr 49:1471-1481

Woelfel J, Schumann R, Adler S, Hübener T, Karsten U (2007) Diatoms inhabiting a wind flat of the Baltic Sea: species diversity and seasonal succession. Estuar Coast Shelf Sci 75:296-307

Woelfel J, Schumann R, Leopold P, Wiencke C, Karsten U (2009a) a Microphytobenthic biomass along gradients of physical conditions in Arctic Kongsfjorden, Svalbard. Bot Mar 52:573-583

Woelfel J, Sørensen K, Warkentin M, Forster S, Oren A, Schumann R (2009b) Oxygen evolution in a hypersaline crust: photosynthesis quantification by in situ microelectrode profiling and planar optode spots in incubation chambers. AME 56:263-273

Wulff A, Vilbaste S, Truu J (2005) Depth distribution of photosynthetic pigments and diatoms in the sediments of a microtidal fjord. Hydrobiologia 534:117-130

Wulff A, Iken K, Quartino ML, Al-Handal A, Wiencke C, Clayton MN (2009) Biodiversity, biogeography and zonation of benthic micro- and macroalgae in the Arctic and Antarctic. Bot Mar 52:491-507 